\section{HELYZETKÉP A MEZŐGAZDASÁGI BIZTOSÍTÁSOK ALAKULÁSÁRÓL}

Bábáné Demeter Edit (osztályvezető, Agrárgazdasági Kutató Intézet)

\section{ÖSSZEFOGLALÓ}

Magyarországon 2017-ben a mezőgazdasági termelők 13,3 milliárd forint növénybiztosítási díjat fizettek ki, és 10 milliárd forint után kívánták igénybe venni az utólagos állami támogatást. A dijjtámogatott biztosítások minden típusánál növekedett a szerződések száma 2016-hoz képest, tehát egyre több gazda élt a lehetőséggel, és vette igénybe ezt a biztosítási formát.

\section{SUMMARY}

In Hungary, in 2017, farmers paid HUF a 13.3 billion flat-rate crop insurance premium and claimed HUF10 billion forints follow-up state subsidies. The number of contracts increased all types of premium-subsidised insurance compared to 2016, so more farmers have taken the opportunity to use this form of insurance.

Kulcsszavak: mezőgazdasági biztosítás

Keywords: agricultural insurance

JEL: G22, Q10

DOI: $10.18530 /$ BK.2018.3.92

http://dx.doi.org/1018530/BK.2017.3.92
A mezőgazdasági biztosítások adatai az agrárium számára igen nagy jelentőséggel bírnak. Az Agrárgazdasági Kutató Intézet (AKI) 2016-tól indított kötelező adatgyűjtést, amely az „OSAP 2416 Mezőgazdasági biztosítások” címet kapta. A beérkezett és feldolgozott adatok alapján az AKI évente jelentést készít, melyet a Magyar Biztosítók Szövetségének és a Magyarországi Nonprofit Biztosító Egyesületek Szövetségének is megküld, illetve az AKI honlapján is közzétesz.

\section{Az adatgyüjtés módszertana}

Az adatszolgáltatás a statisztikáról szóló 2016. évi CLV. törvény (Stt.) 26. \$-a alapján kötelezö, és a törvény felhatalmazása alapján kiadott Országos Statisztikai Adatgyüjtési Programról (OSAP) szóló kormányrendelet szerint történik. Az AKI által begyüjtött információk a 2017-es évre vonatkozóan a mezőgazdasági biztosításokkal foglalkozó biztosítók és biztosítóegyesületek adatait tartalmazzák. Az adatok beküldési határideje a tárgyévet követő év február 28. A biztosítóknak és biztosítási egyesületeknek a mezőgazdasági biztosítások üzleti adatait kockázati csoportok szerint bontva kellett a tárgyévre vonatkozóan megadniuk. Az adatszolgáltatási kötelezettségének minden kijelölt adatszolgáltató eleget tett. Az MNB meghatározásaival összhangban a kérdőíven a „Csomagbiztosítások” egy darabnak számítottak, és a termék dijfelosztásakor kapott legnagyobb arányú díjrész szerinti biztosítási kockázati csoporthoz kellett az adatszolgáltatáskor beírni az összeget. A besorolás megtörténte után az adott biztosítások adatai (így a kárfizetése is) egyazon soron kellett, hogy szerepeljenek. Az adatok között csak a termelőkkel közvetlenül kötött biztosításokat kértük feltüntetni, a viszontbiztosításokat nem. A biztosításokról szóló jelentés a 19 magyarországi mezőgazdasági biztosítással foglalkozó biztosítótársaság és biztosítóegyesület adatai alapján készült, amelyek közül 3 biztosítóegyesület nem kötött mezőgazdasági biztosítást 2017-ben. A beérkezett adatokat az adatvédelmi eloírásoknak megfelelően, kizárólag statisztikai célra használjuk fel, személyes adatokat harmadik fél részére nem adunk ki.

\section{A mezőgazdasági biztosítások főbb jellemzői Magyarországon 2017-ben}

Az agrárbiztosítások piacának alakulásában, fejlődésében jelentős szerepet játszik az igényelhető állami támogatás, mivel a termelők egyre inkább a díjtámogatott konstrukciót választják. A díjtámogatott agrárbiztosítási rendszer 2017-ben már hatodik éve működik, amelynek keretében a gazdálkodók a támogatott körbe tartozó biztosítások díjának legfeljebb 65 százalékát utólagos támogatásként visszakaphatják (túligénylés esetén visszaosztásra kerül sor). A konstrukció népszerűsége egyre nő, amiben kiemelt szerepet játszott, hogy 2016-ban visszatérhettek a rendszerbe egyes nagyvállalatok, valamint az állami és önkormányzati szereplők is, így a díjtámogatott szerződések állománydíja tovább növekedett, a tavalyi 7,86 milliárdról 10,02 milliárd forintra 2017-ben. Magyarországon a gazdálkodók 13,3 milliárd forint növénybiztosítási díjat fizettek be 
a biztosítók és biztosítóegyesületek részére 2017-ben, amiből 10,02 milliárd forint után kívánták a termelők igénybe venni az utólagos állami díjtámogatást.

A növénybiztosítási ágazat hegemóniája továbbra is fennáll, hiszen 2016-ban az összes mezőgazdasági biztosítási díjbevételnek 86, míg 2017-ben 87 százalékát adta ez a biztosítási ág. Az állatbiztosítások részesedése 2017-ben az összes díjbevételből 3,9 százalék, a vagyon- és felelősségbiztosításoké 9,0 százalék volt, míg az erdőbiztosításoké 2016-hoz képest változatlan maradt.

Az agrárbiztosítások piacának alakulásában, fejlődésében jelentős szerepet játszik az igényelhető állami támogatás.

Az időjárás szélsőségesen alakult 2017-ben a mezőgazdaság számára, a legjelentősebb károkat az aszály, az esőzések, a tavaszi fagyok, a vihar- és jégkárok okozták a gazdálkodóknak. A helyi károk intenzitása évről évre egyre erősebb, ami az időjárás szélsőséges jellegének fokozódását is mutatja. A mezőgazdasági jég- és viharkárok sok tájegységben előfordultak, de viszonylag kis körzetekben jelentkeztek intenzív formában. A mezőgazdasági termelők leginkább jégkárra kötöttek biztosítást 2017-ben, és azok a konstrukciók, amelyek a jégkárt is tartalmazzák, a jövőben is népszerüek maradnak. Emellett a szerződésszám jelentősen emelkedett (megnégyszereződött) 2017-ben a téli fagyokra kötött biztosítások esetén.

\section{Mezőgazdasági biztosítások kárnemenkénti alakulása 2017-ben}

A mezőgazdasági díjbevételek összesen 15295 millió forintot, míg a kárfizetések 10 697,5 millió forintot tettek ki 2017-ben. Az állatbiztosítási ágazat 2017. évi díjbevétele 603,8 millió forintot, kárfizetése 237,8 millió forintot (csökkenve az előző évhez képest) ért el, a vagyon- és felelősségbiztosítások díjelőírása 1382,1 millió forint, kárfizetése 701,9 millió forint volt. A mezőgazdasági biztosítások átlagos kárhányada 2017-ben 69,4, a növénybiztosításoké 72,7, az állatbiztosításé 39,0 százalék volt, míg a vagyon- és felelősségbiztosítás kárhányada 50,8 százalékot tett ki (1. ábra).
1. ábra: A kárhányadok alakulása a főbb biztosítási csoportoknál Magyarországon a 2016-os és 2017-es évben

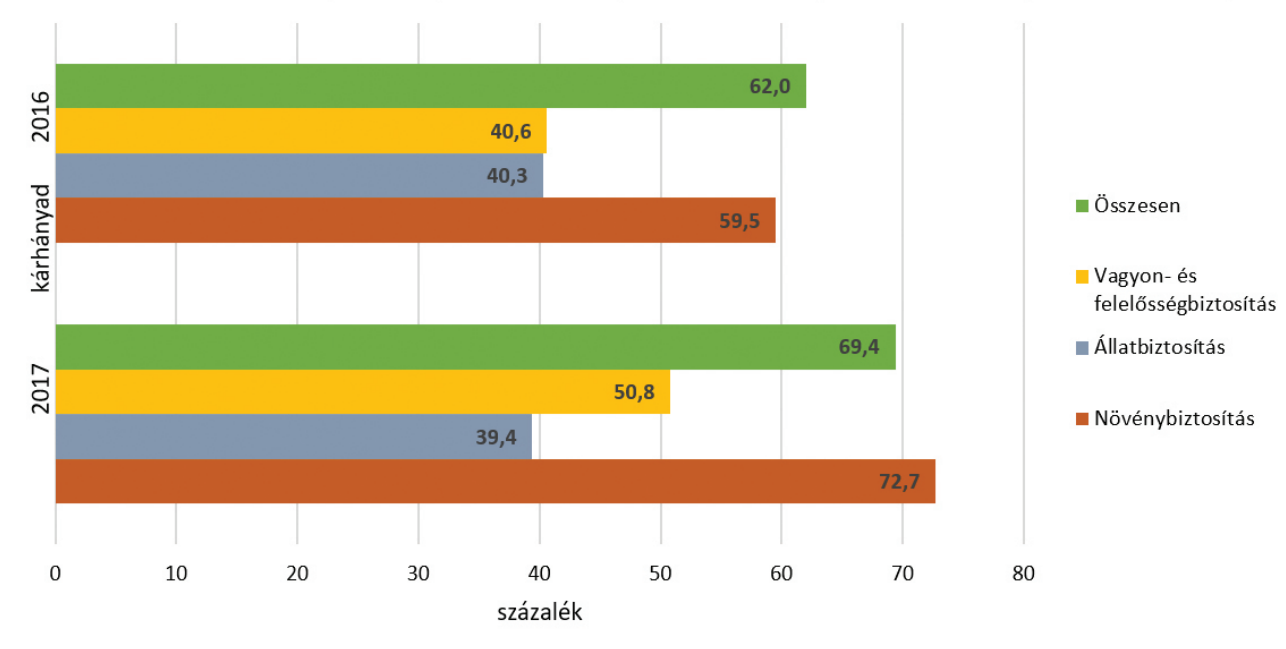

Forrás: AKI Agrárstatisztikai Információs Osztály

A hatályos jogszabályok szerint a hazai díjtámogatott biztosítási piacon az „A” típusú növénybiztosítás az összes díjtámogatott és a hozzá kapcsolódó kiegészítő biztosítások díjelőírásának 45,5 százalékát, kárfizetésének pedig 21,2 százalékát tette ki 2017-ben. A díjtámogatott növénybiztosításból (a kiegészítő biztosítások elhagyásával) a legnagyobb részesedést az „A” típusú érte el: a díjbevételek 47,4 százalékát, míg a kárkifizetések 45,1 százalékát adta. A kárhányadok 2017-ben az előző évhez viszonyítva a díjtámogatott növénybiztosításoknál a „B” típus esetén emelkedtek, a többinél csökkentek. A díjtámogatott növénybiztosítás átlagos kárhányada 36,0 százalékot tett ki 2017-ben. A kiegészítő biztosításkötések figyelembevételével - amelyeket a díjtámogatott biztosításokra kötöttek - 2017-ben a kárhányad 73,3 százalékra emelkedett, ami 12,0 százalékpontos növekedés 2016-hoz képest.

A jég és tűz kockázati tényező esetén 79,3, vihar esetén 6,3 százalékos kárhányad keletkezett 2017-ben. Az összes növénybiztosítást vizsgálva a legnagyobb mértékű, 939,2 százalékos kárhányad a kiegészítő biztosításoknál keletkezett. A növénybiztosítások esetén az átlagos kárhányad 72,7 százalék volt 2017-ben (2. ábra). 
2.ábra: A növénybiztosítások dijjlőírásánakés kárfizetésének alakulása kockázati tényezőkszerint 2017-ben

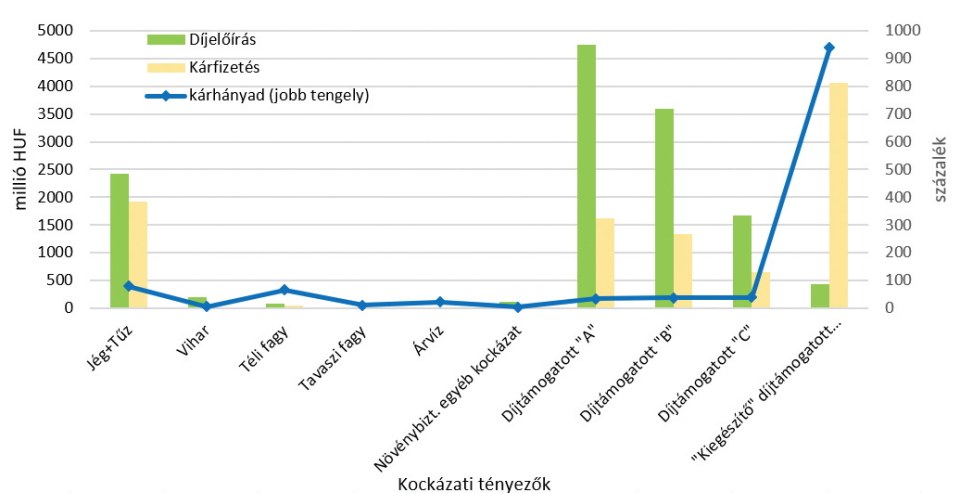

Forrás: AKI Agrárstatisztikai Információs Osztály

A díjtámogatott biztosítási szerződések száma 2017-ben minden típusnál erős növekedést mutatott, tehát egyre több gazda élt a lehetőséggel, és vette igénybe ezt a biztosítási formát. Közel kétszeresére nőtt a kiegészítő szerződések száma, és több mint 50 százalékkal emelkedett az „A” típusú szerződésszám 2017-ben. A díjtámogatott biztosításokról a Biztosítás és Kockázat IV. évfolyam 2. számában olvashatnak az érdeklődők (Gazdag Gyula - Tanczné Óvári Csilla: Indokolt az optimizmus a díjtámogatott növénybiztosítások kapcsán, illetve Füzesi Dániel: A díjtámogatott növénybiztosítás az első öt év tükrében).

További információk az Agrárgazdasági Kutató Intézet (AKI) honlapján (https:// www.aki.gov.hu/) találhatók, illetve a mezőgazdasági biztosításokról szóló statisztikai jelentések az alábbi linken: https://www.aki.gov.hu/agrarstatisztikai-informacios-rendszer érhetök el.

\section{IRODALOMJEGYZÉK}

Bábáné Demeter Edit (2017): Mezőgazdasági biztositások 2016. báné Demeter Edit (2018): Mezőgazdasági biztositások 2017. 